\title{
Differential activity of a lectin from Solieria filiformis against human pathogenic bacteria
}

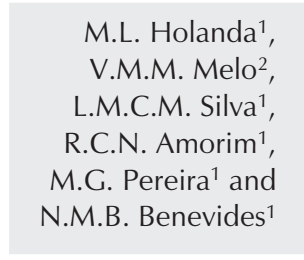

\section{Correspondence}

N.M.B. Benevides

Departamento de Bioquímica e

Biologia Molecular

Universidade Federal do Ceará

Rua Dr. Gilberto Studart, 2155/302A

60190-750 Fortaleza, CE

Brasil

Fax: +55-85-288-9789

E-mail:nmbb@ufc.br

Research supported by CAPES, CNPq and FUNCAP.

Received June 18, 2004

Accepted August 11, 2005

$\ldots \ldots \ldots \ldots \ldots \ldots$

\author{
${ }^{1}$ Departamento de Bioquímica e Biologia Molecular, \\ ${ }^{2}$ Departamento de Biologia, Universidade Federal do Ceará, \\ Fortaleza, CE, Brasil
}

\begin{abstract}
A lectin isolated from the red alga Solieria filiformis was evaluated for its effect on the growth of 8 gram-negative and 3 gram-positive bacteria cultivated in liquid medium (three independent experiments/ bacterium). The lectin $(500 \mu \mathrm{g} / \mathrm{mL})$ stimulated the growth of the grampositive species Bacillus cereus and inhibited the growth of the gramnegative species Serratia marcescens, Salmonella typhi, Klebsiella pneumoniae, Enterobacter aerogenes, Proteus sp, and Pseudomonas aeruginosa at $1000 \mu \mathrm{g} / \mathrm{mL}$ but the lectin $(10-1000 \mu \mathrm{g} / \mathrm{mL})$ had no effect on the growth of the gram-positive bacteria Staphylococcus aureus and B. subtilis, or on the gram-negative bacteria Escherichia coli and Salmonella typhimurium. The purified lectin significantly reduced the cell density of gram-negative bacteria, although no changes in growth phases (log, exponential and of decline) were observed. It is possible that the interaction of $S$. filiformis lectin with the cell surface receptors of gram-negative bacteria promotes alterations in the flow of nutrients, which would explain the bacteriostatic effect. Growth stimulation of the gram-positive bacterium B. cereus was more marked in the presence of the lectin at a concentration of $1000 \mu \mathrm{g} / \mathrm{mL}$. The stimulation of the growth of B. cereus was not observed when the lectin was previously incubated with mannan $(125 \mu \mathrm{g} / \mathrm{mL})$, its hapten. Thus, we suggest the involvement of the binding site of the lectin in this effect. The present study reports the first data on the inhibition and stimulation of pathogenic bacterial cells by marine alga lectins.
\end{abstract}

Lectins are present in almost all living organisms. The main characteristic of this class of proteins is the ability to interact specifically and reversibly with carbohydrates and thus to combine with glyco-components on the cell surface (1). A number of possible physiological roles have been pro-
Key words

- Red alga

- Solieria filiformis

- Human pathogenic bacteria

- Lectin

- Antibacterial activity

- Klebsiella pneumoniae posed for lectins, most of which are based on specific carbohydrate binding and recognition of the molecules and biological structures that contain these sugars (2). Lectins from terrestrial plants and animals have been isolated, characterized and studied extensively in many aspects of biochemistry and 
biomedicine. In contrast, only a limited amount of information about lectins from seaweed is available, mainly due to difficulties in isolating and obtaining sufficient material for study (3). In general, algal lectins have a lower molecular mass than most higher plant lectins and have no affinity for simple sugars, being more specific for complex oligosaccharides, often glycoproteins (3). Most of the algae from which lectin has been obtained and purified belong to the Rhodophyta $(4,5)$. Benevides et al. (4) purified and characterized the lectin from the red alga Solieria filiformis as having a low molecular mass of $29 \mathrm{kDa}$ and agglutinating activity inhibited by the glycoproteins mannan, avidin, ovalbumin, and egg white.

Few reports have been published on the use of lectin or lectin-like substances from plants as inhibitors of fungal and bacterial growth (6-11). Yet, the concentration of these proteins offers great potential for differential cell recognition (12). Therefore, in this paper we report the action of the lectin from S. filiformis seaweed on the growth of 11 pathogenic species of bacteria.

The marine red alga S. filiformis (Kützing Gabrielson) was collected from Pacheco beach (Fortaleza, CE, Brazil). After collection, the material was separated from epiphytes, washed with distilled water and stored at $-20^{\circ} \mathrm{C}$ until use. Purification is described below.

Gram-positive bacterial strains of Bacillus cereus, B. subtilis and Staphylococcus aureus, and gram-negative bacterial strains of Escherichia coli, Serratia marcescens, Salmonella typhi, S. typhimurium, Klebsiella pneumoniae, Enterobacter aerogenes, Proteus spp, and Pseudomonas aeruginosa were studied. Culture concentrations were adjusted by measuring turbidity at $630 \mathrm{~nm}$ of $10^{3}-10^{4}$ colony-forming units $(\mathrm{CFU}) / \mathrm{mL}$.

The lectin from the marine red alga $S$. filiformis was purified following the protocol described by Benevides et al. (4). Algal material was ground to a fine powder in a mortar and pestle in the presence of liquid nitrogen. The powder was then stirred (1:3, w/v) with $20 \mathrm{mM}$ Tris-HCl buffer (TB), $\mathrm{pH}$ 7.5 , for $4 \mathrm{~h}$ at room temperature. Insoluble algal material was removed by filtration using a nylon membrane followed by centrifugation at $6000 \mathrm{~g}$ for $30 \mathrm{~min}$ at $4^{\circ} \mathrm{C}$. The crude, clear extract was submitted to treatment with solid ammonium sulfate $(80 \%$ saturation) and the resulting precipitate $(\mathrm{F} 0 /$ 80) was recovered in TB and centrifuged at $16,000 \mathrm{~g}$ for $20 \mathrm{~min}$ at $4^{\circ} \mathrm{C}$. The clear supernatant was applied to an affinity chromatography on a Mannan-Sepharose 4B column $(8 \times 0.8 \mathrm{~cm})$. The column was equilibrated with TB and unbound proteins were removed by elution with the equilibrium buffer. The retained lectin was then desorbed from the matrix by the addition of a 4.0-M urea solution to the gel. Fractions showing hemagglutinating activity were pooled, dialyzed against distilled water, freeze-dried, and assessed by discontinuous electrophoresis according to the method of Laemmli (13). A $12.5 \%$ polyacrylamide slab in $25 \mathrm{mM}$ Tris- $\mathrm{HCl}, 0.2 \mathrm{M}$ glycine, $\mathrm{pH} 8.9$, with $0.1 \%$ sodium dodecyl sulfate was used. Sample and standards were prepared in $25 \mathrm{mM}$ Tris-HCl buffer, $\mathrm{pH} 6.8$, containing $1.0 \%$ SDS and $1.0 \%$ B-mercaptoethanol. The picrate-Coomassie blue method, as described by Stephano et al. (14), was used to detect proteins. Hemagglutination assays were carried out using $2 \%$ trypsintreated fresh rabbit erythrocytes (5). Proteins were estimated by the Bradford method (15) using bovine serum albumin as the standard.

Inhibition of bacterial growth was evaluated by determining the concentration of lectin that reduced culture growth compared to control according to the procedures described by Broekaert et al. (16). Ten microliters of the cultures was added to each well of 96-well microtiter plates (NUNC, Corning, NY, USA) containing nutritive broth (Merck, Darmstadt, Germany) with two-fold serial dilutions of the lectin (10-1000 $\mu \mathrm{g} /$ 
$\mathrm{mL})$. The plates were incubated at room temperature for a period of $48 \mathrm{~h}$ and turbidity was measured (20, 24 and $48 \mathrm{~h})$ at $630 \mathrm{~nm}$ using a UV-visible spectrophotometer (Elx 800, Bio Tek ${ }^{\circledR}$ Inst., Inc., Winooski, VT, USA). The same assay was used to evaluate the action of the lectin on bacterial growth in the presence of its hapten. For this assay, the lectin was previously incubated with mannan at a concentration of $125 \mu \mathrm{g} / \mathrm{mL}$ at $37^{\circ} \mathrm{C}$ for $1 \mathrm{~h}$. The number of bacterial cells was obtained by counting viable colonies on the plates by the method of Collins et al. (17). All experiments were run in triplicate, and the averages of the readings, the standard errors and coefficients of variation were calculated.

Data were analyzed statistically by oneway analysis of variance (ANOVA) (General Linear Models in the GLM procedure) using MSTATC software, with the level of significance set at $\mathrm{P}<0.05$.

Purified lectin from the $S$. filiformis alga was prepared by extraction of fresh algal tissue in $20 \mathrm{mM}$ Tris- $\mathrm{HCl}$ buffer, $\mathrm{pH}$ 7.5. The proteins were precipitated with $80 \%$ saturated ammonium sulfate $(0-80 \%$ protein fraction), followed by affinity chromatography on a Mannan-Sepharose 4B column. The lectin preparation exhibited a single protein band with a molecular mass of 29 $\mathrm{kDa}$ on sodium dodecyl sulfate polyacrylamide gel and showed hemagglutinating activity against trypsin-treated rabbit erythrocytes (Figure 1).

The $S$. filiformis lectin at a concentration of $1000 \mu \mathrm{g} / \mathrm{mL}$ had an inhibitory effect on the growth curve of the gram-negative bacteria S. marcescens (growth curve not shown), S. typhi, K. pneumoniae, E. aeroge$n e s$, Proteus spp, and $P$. aeruginosa compared to control. This inhibitory effect significantly reduced $(\mathrm{P}<0.05)$ the cell density of bacterial solutions at $24 \mathrm{~h}(21.6,26.8$, $27.4,20.7,18.9$, and $24.5 \%$, respectively) without any alterations in the profile of the growth curve (Figure 2A-E). A decrease in the number of bacterial cells was detected by counting viable colonies on the plates when the bacterial suspensions of E. aeroge$n e s$ and $P$. aeruginosa were incubated with the $S$. filiformis lectin $\left(0.3 \times 10^{9}\right.$ and $0.5 \times 10^{9}$ $\mathrm{CFU} / \mathrm{mL}$, respectively) and compared to the control $\left(3.2 \times 10^{9}\right.$ and $4.9 \times 10^{9} \mathrm{CFU} /$ $\mathrm{mL})$.

The inhibitory effect of the lectin on the growth of these bacterial species could be due to its interaction with the glycoconjugate mannan, its hapten, present on the surface of the cell walls of gram-negative bacteria. Strathmann et al. (18) observed that the lectin from Canavalia ensiformis seeds labeled with fluorescein isothiocyanate was capable of interacting with carbohydrates (hyaluronic acid, glucose, galactose, mannose, ribose, rhamnose, glucosamine, and galactosamine) of extracellular polymeric substances produced by the gram-negative bacteria $P$. aeruginosa. In contrast, the $S$. filiformis lectin had no effect on the growth

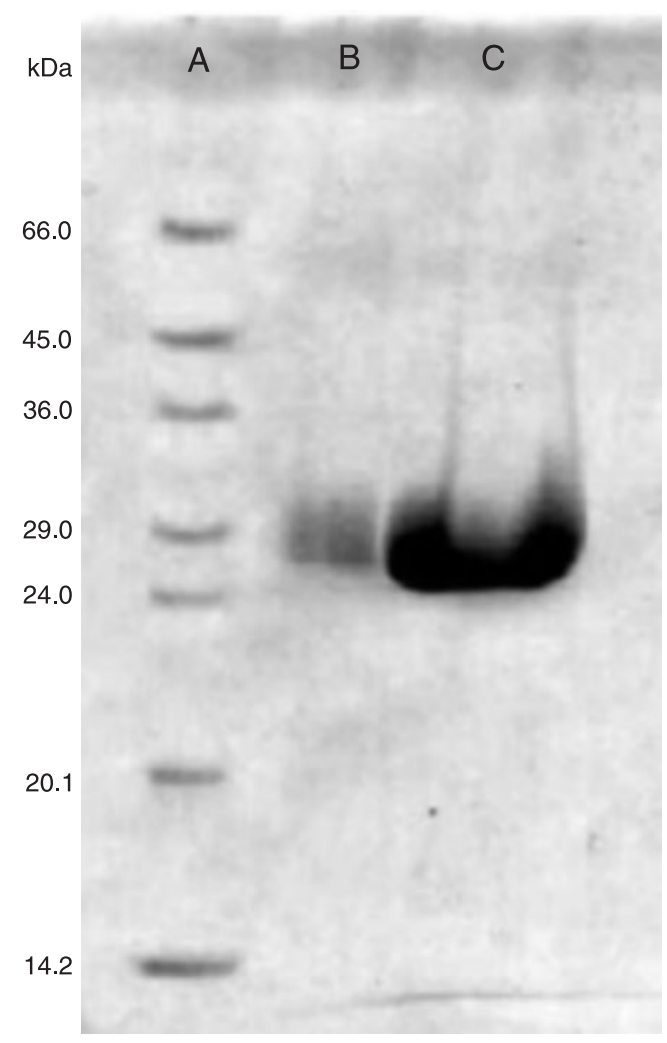

Figure 1. SDS-PAGE of a lectin purified from Solieria filiformis. $A$, Protein mass standards: 14.2-kDa $\alpha$-lactoalbumin, 20.1$\mathrm{kDa}$ trypsin inhibitor, 24.0-kDa trypsinogen, 29.0-kDa carbonic anhydrase, 36.0-kDa glyceraldehyde-3-phosphate dehydrogenase, 45.0-kDa ovalbumin, and 66.0-kDa bovine serum albumin. $B$ and $C$, Purified lectin (5.0 and $20.0 \mu \mathrm{g}$, respectively). 
of the gram-negative bacteria $E$. coli and $S$. typhimurium or on the gram-positive bacteria $B$. subtilis and $S$. aureus at any of the concentrations tested (data not shown). This might be due to the absence of specific carbohydrates on the surface of the cell walls of these bacteria or to inaccessibility of these carbohydrates to $S$. filiformis lectin. Indeed, red blood cells become more sensitive to agglutination by seaweed lectins when they
A

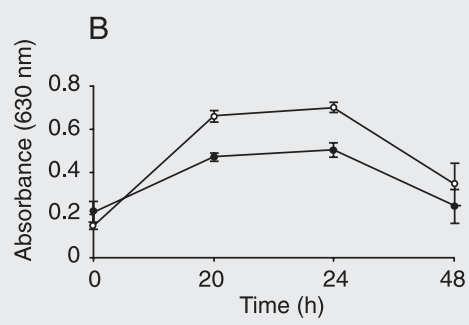

C

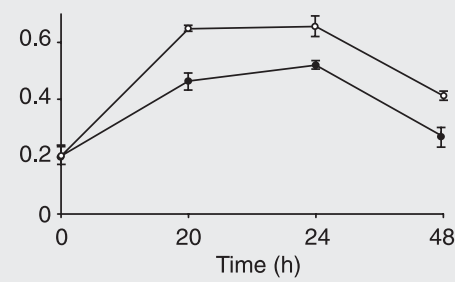

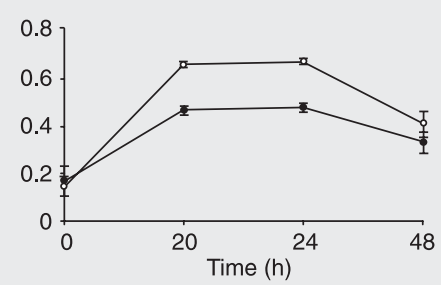

D

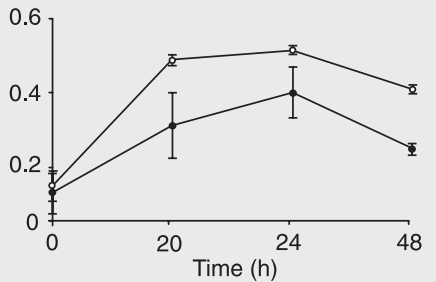

$E$

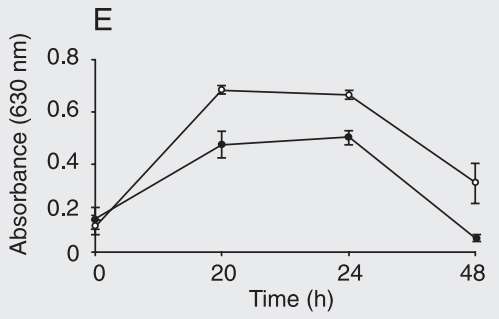

$\mathrm{F}$

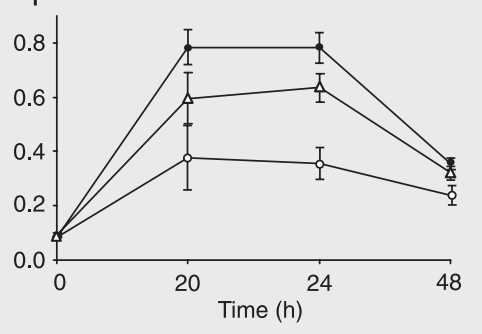

Figure 2. Effect of the Solieria filiformis lectin on the growth of gram-negative and grampositive bacteria Salmonella typhi (A), Krebsiella pneumoniae (B), Enterobacter aerogenes (C), Proteus spp (D), Pseudomonas aeruginosa (E) and Bacillus cereus (F). Absorbance at $630 \mathrm{~nm}$ was used as a measurement of bacterial growth. Control (open circles), $500 \mu \mathrm{g} / \mathrm{mL}$ lectin (triangles), and $1000 \mu \mathrm{g} / \mathrm{mL}$ lectin (filled circles). Data are reported as the mean $\pm \mathrm{SD}$ for three experiments. are treated with bromelain and trypsin, respectively $(5,19)$, removing and/or exposing some of the membrane glycoproteins to facilitate bridge formation between cells without necessarily affecting the total number of lectin binding sites (20).

The lectin of S. filiformis at a concentration of $500 \mu \mathrm{g} / \mathrm{mL}$ had a statistically significant stimulatory effect $(\mathrm{P}<0.05)$ only on the cell density of solutions of the gram-positive bacteria B. cereus at $24 \mathrm{~h}(78 \%)$ compared to control. This stimulatory effect was highest at a concentration of $1000 \mu \mathrm{g} / \mathrm{mL}(126 \%)$, demonstrating a dose-effect relationship (Figure $2 \mathrm{~F}$ ).

The inhibitory and stimulatory effects on bacterial growth were eliminated when the lectin was previously incubated with the hapten mannan, confirming the interaction of lectin with glycoconjugates present on the surface of the bacterial cell wall.

It is possible that the interaction of $S$. filiformis lectin with receptors on the surface of gram-negative bacteria promotes alterations in the flow of nutrients, thereby explaining the bacteriostatic effect.

An increase in the number of $B$. cereus cells was observed when the number of viable colonies on the plates containing the bacterial suspension incubated with the $S$. filiformis lectin $\left(2.0 \times 10^{8} \mathrm{CFU} / \mathrm{mL}\right)$ was counted and compared to control $\left(2.0 \times 10^{5}\right.$ $\mathrm{CFU} / \mathrm{mL}$ ).

The fact that $S$. filiformis lectin had both stimulatory and inhibitory effects on the growth of pathogenic bacteria is intriguing and further studies are needed to evaluate the significance of the action of this protein on bacterial growth for clinical microbiology and possible therapeutic applications. 


\section{References}

1. Weis WI \& Drickamer K (1996). Structural basis of lectin-carbohydrate recognition. Annual Review of Biochemistry, 65: 441-473.

2. Kocourek J \& Horejsi $V$ (1983). A note of the recent discussion on definition of the term "lectin". In: Bog-Hansen TC \& Spengler GA (Editors), Lectins: Biology, Biochemistry, Clinical Biochemistry. Vol. 3. Walter de Gruyter \& Co., Berlin, Germany, 3-6.

3. Rogers DJ \& Hori K (1993). Marine algal lectins: new developments. Hydrobiologia, 260/261: 589-593.

4. Benevides NMB, Leite AM \& Freitas ALP (1996). Atividade hemaglutinante na alga vermelha Solieria filiformis. Revista Brasileira de Fisiologia Vegetal, 8: 117-122.

5. Benevides NMB, Holanda ML, Melo FR et al. (1998). Purification and partial characterization of the lectin from the marine red alga Enantiocladia duperreyi (C. Agardh) Falkenberg. Botanica Marina, 41: 521-525.

6. Mirelmam D, Galun E, Sharon N et al. (1975). Inhibition of the fungal growth by wheat germ agglutinin. Nature, 256: 414-416.

7. Criado MT \& Ferreiros CM (1983). Selective interaction of a Fucus vesiculosus lectin-like mucopolysaccharide with several Candida species. Annales de Microbiologie, 134A: 149-154.

8. Broekaert WF, Parijs JV, Leyns F et al. (1989). A chitin-binding lectin from stinging nettle rhizomes with antifungal properties. Science, 245: 1100-1102.

9. Melo VMM, Medeiros DA, Rios FJB et al. (1997). Antifungal properties of proteins (agglutinins) from the red alga Hypnea musciformis (Wulfen) Lamouroux. Botanica Marina, 40: 281-284.

10. Freire MGM, Gomes VM, Corsini RE et al. (2002). Isolation and partial characterization of a novel lectin from Talisia esculenta seeds that interfere with fungal growth. Plant Physiology and Biochemistry, 40: $61-68$

11. Gaidamashvili M \& Van Staden J (2002). Interaction of the lectin-like proteins of South African medicinal plants with Staphylococcus aureus and Bacillus subtilis. Journal of Ethno-Pharmacology, 80: 131-135.

12. Fabregas J, Muñoz A, Llovo J et al. (1989). Differentiation of Candida. Research Microbiology, 140: 373-378.

13. Laemmli UK (1970). Cleavage of structural proteins during the assembly of the head of bacteriophage $t_{4}$. Nature, 227: 680-685.

14. Stephano JL, Gould M \& Rojas-Galicia L (1986). Advantages of picrate fixation for staining polypeptides in polyacrylamide gels. Analytical Biochemistry, 152: 308-313.

15. Bradford MM (1976). A rapid and sensitive method for the quantification of microgram quantities of protein utilizing the principle of protein-dye binding. Analytical Biochemistry, 72: 248-254.

16. Broekaert WF, Terras FRG, Cammue PA et al. (1990). An automated quantitative assay for fungal growth inhibition. FEMS Microbiology Letters, 69: 55-60.

17. Collins CH, Lyne PN \& Grange JM (1989). Collins and Lyne's Microbiological Methods. 6th edn. Butterworth \& Co., Ltd., London, England, 127-129.

18. Strathmann M, Wingender J \& Flemming HC (2002). Application of fluorescently labeled lectins for the visualization and biochemical characterization of polysaccharides in biofilms of Pseudomonas aeruginosa. Journal of Microbiological Methods, 20: 237-248.

19. Benevides NMB, Holanda ML, Melo FR et al. (2001). Purification and partial characterization of the lectin from the marine green alga Caulerpa cupressoides (Vahl) C. Agardh. Botanica Marina, 44: 1222.

20. Sharon N \& Lis H (2003). Detection, occurrence and isolation. In: Sharon N \& Lis H (Editors), Lectins. Kluwer Academic Publishers, Dordrecht, Netherlands, 33-61. 